\title{
Elektronikus könyvek beszerzési modelljei a ProQuest Ebook Central platformján
}

A Wikipédia meghatározása szerint: ,az e-könyv (angolul e-book) az elektronikus formában létrehozott és terjesztett szöveget és egyes esetekben képet tartalmazó fájl, amely digitális megfelelöje a nyomtatott könyvnek."1

A ProQuest e-könyv-platformja, a ProQuest Ebook Central felhasználóbarát, komplex élményt nyújt modern és intuitív olvasói oldalával. Az adminisztrátori felület, a LibCentral segíti a könyvtárosok munkáját a különféle beállítások testreszabásában, az egyes munkafolyamatok kezelésében: lehetőséget nyújt például az olvasók használati szokásainak követésére, a rekordok MARC formátumban történő letöltésére és a költségstatisztikák lekérdezésére.

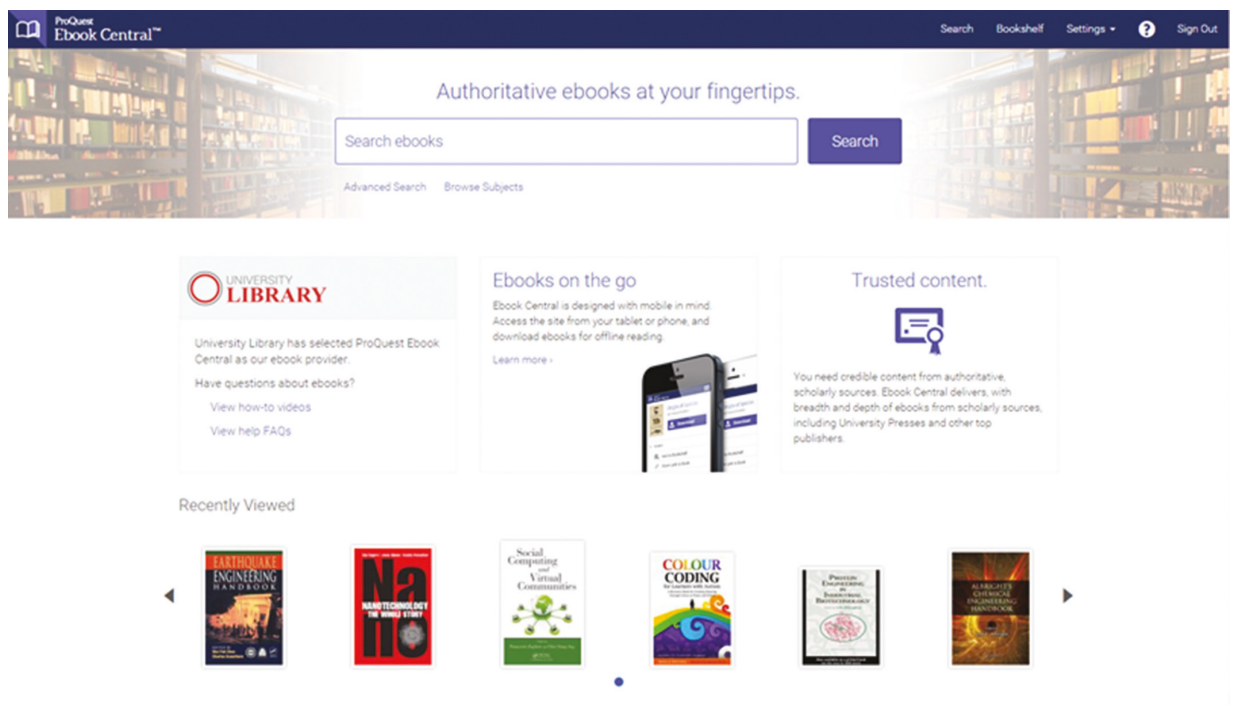

1. ábra. ProQuest Ebook Central

A ProQuest Ebook Centralon keresztül több mint egymillió elektronikus könyv érhető el hozzávetőleg 1200 tudományos és egyetemi kiadótól, többféle beszerzési modellen keresztül. Az e-könyvek mind asztali számítógépen, mind laptopon vagy mobileszközökön - telefonon, tableten, e-könyv-olvasón - elindíthatók, online és offline módon egyaránt.

${ }^{1}$ E-könyv. https://hu.wikipedia.org/wiki/E-könyv (2019. március 19.) 


\section{Miért e-könyvek?}

Az elektronikus könyv több mint a nyomtatott kiadvány elektronikus verziója, hiszen nemcsak olvasni lehet, hanem a számítógépes múveletek is egyszerủen elvégezhetők benne. Például az alábbiak:

- Az online olvasás mellett kimásolhatók egyes részek egy saját dokumentumba, nyomtatni lehet belölük, valamint a hivatkozási szabályoknak megfelelö formájú idézet készítése is lehetséges. S mindehhez semmilyen további szoftver nem szükséges! A nyomtatott verzió olvasása esetén ezek a mủveletek sokkal több munkát igényelnének. Gondoljunk például csak az idézésre, a kiválasztott mondatok, bekezdések begépelésére!

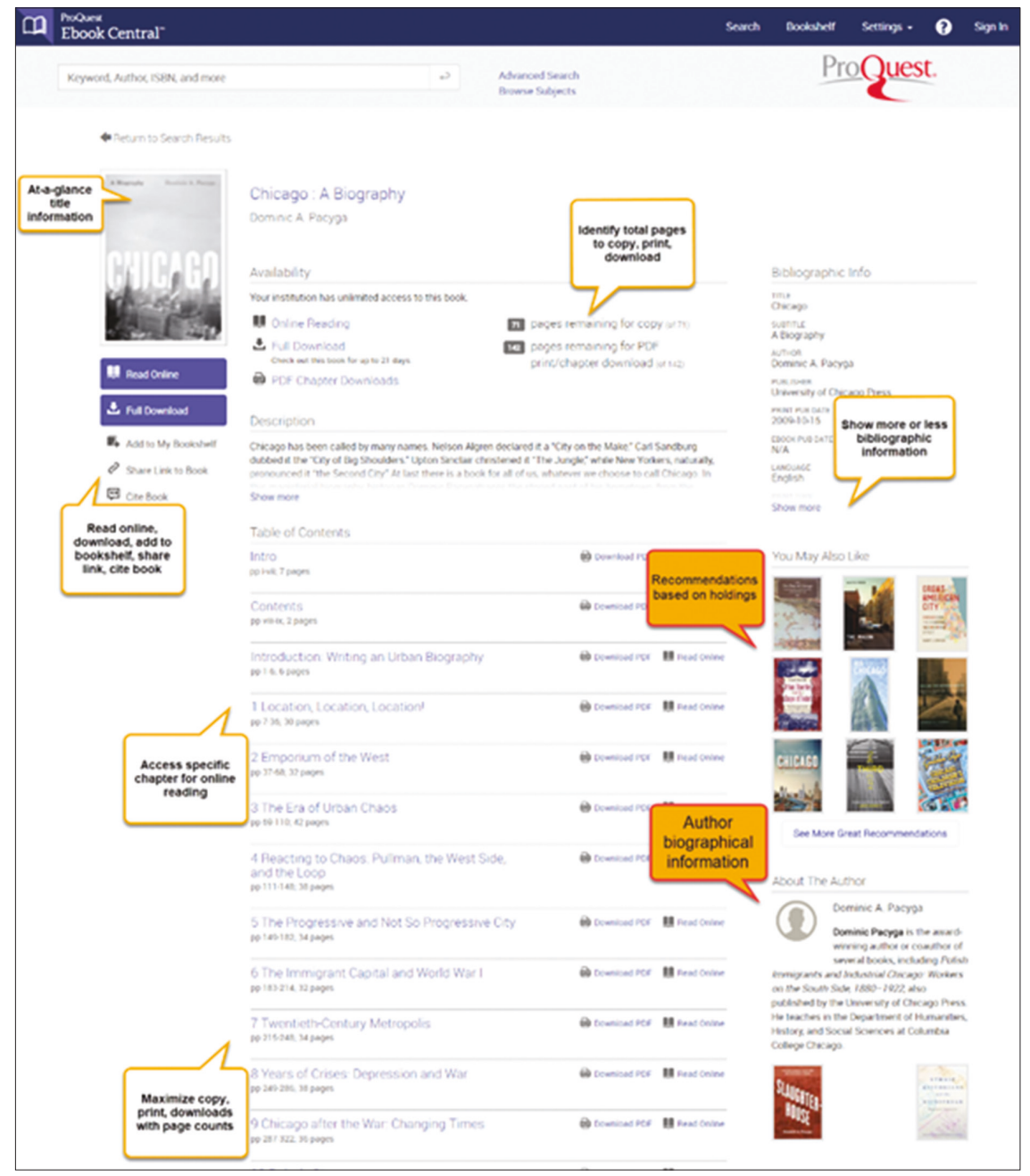

2. ábra. E-könyv - áttekintés 
- Az e-könyvek kölcsönzése a letöltés (download) funkcióval történik, és a nyomtatott könyvekhez hasonlóan meghatározott időre, egy, hét, tizennégy vagy huszonnyolc napra szól. Amennyiben nyomtatunk, a kiválasztott oldalak, fejezetek pdf-formátumban a saját gépünkön maradnak.

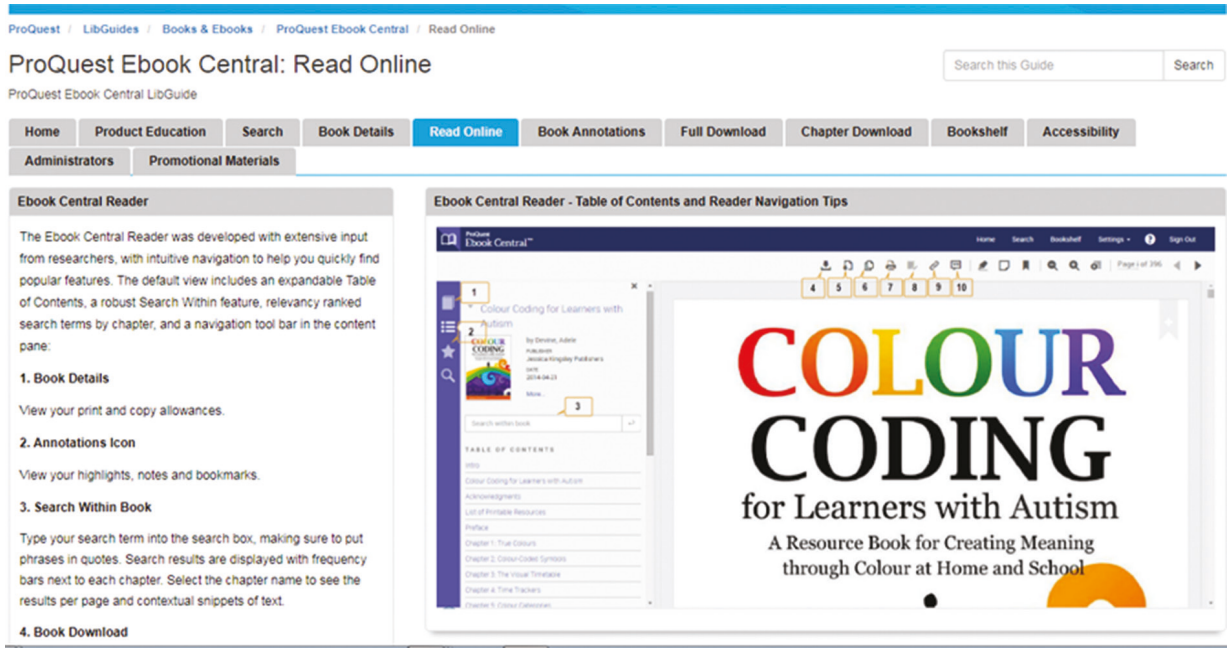

3. ábra. Online olvasás

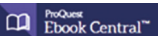

a

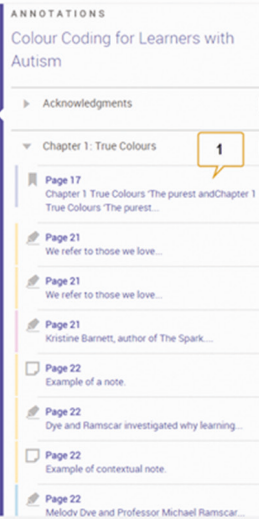

\section{Home search Bookshet setrings. ? sign ou}

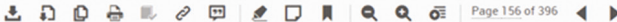
\begin{tabular}{l|l|l|l|l|l|l}
\hline & 5 \\
\hline
\end{tabular}

COLOUR CODING FOR LEARNERS WITH AUTISM

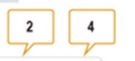

Fireworks

Fireworks - we love them or hate them. Peopl 10 , love
fireworks for the colour, the sensory and the excitement. They may also hate fireworks for the colour, the sensory and the excitement. They may also hate the noise, the change in ro

Darkness and light, and day and night happen. We can control the lights in the house, but not the sun, moon and stars. It gets darker and quieter at night. People sleep. The curtains are closed. We bath, we go to bed.

Then there is this one night when it all changes. The sky is full of big

bangs and explosions, and huge crowds gather to look at the sky. They should be inside, in bed. This is confusing and can be quite frightening.

Some children find it difficult to stay outside and watch fireworks. Their fear is real. However, we cannot stop fireworks going off at night. They are something so many people enjoy. Fireworks are no longer restricted to once a year. People seem to need little excuse to light up the night sky with a big bang. There are fireworks at weddings, birthdays, New Year, Christmas,

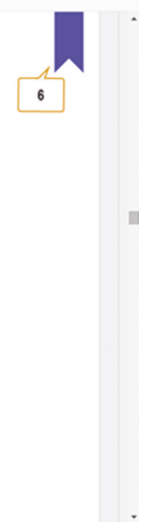

4. ábra. Kijelölés e-könyvben

A megfelelö e-könyv megtalálása mindenki számára egyszerü, mert a ProQuest felületén böngészni és keresni egyaránt lehet, akár egyetlen ismert adat alapján. 
Az összetett keresésben pedig a keresőszavak (például a mü címe, szerzője, kiadója, kiadási éve, ISBN-száma, nyelve) logikai operátorokkal kapcsolhatók össze.

Az Ebook Central e-könyveit az előfizető intézmény IP-hálózatán belül lehet használni, de az ott regisztrált felhasználói névvel és jelszóval otthonról vagy mobileszközről is elérhetővé tehető a gyüjtemény. A könyvtár minden esetben megtartja az ellenőrző funkcióját az elektronikus könyvek fölött.

\section{Beszerzési lehetőségek}

Az Ebook Central elektronikus könyveire a ProQuest többféle beszerzési lehetöséget biztosít a könyvtárak számára:

1. Elöfizetés: ez a beszerzési modell a ProQuest által összeállított multidiszciplináris vagy tudományterületenként összeválogatott csomagokra vonatkozik. Az e-könyveket összesen tíz szakterületbe sorolva - jog, gazdaság, bölcsészet, társadalomtudomány, orvostudomány, nyelvészet és irodalom, történelem, pedagógia, természettudományok és müszaki tudományok, vallás és filozófia - találhatják meg az érdeklődők. A teljes csomag neve Academic Complete, amely körülbelül 158 ezer e-könyvet tartalmaz korlátlan eléréssel.

2. Cím szerinti örökvásárlás esetén a könyvtár a ProQuest Ebook Central oldalán elérhető katalógusból egy konkrét e-könyvet választ ki. Ekkor a vásárló könyvtár határozza meg a dokumentumhoz való egyidejü hozzáférések számát - amely lehet egy, három vagy korlátlan -, az ár pedig e számtól függ. A cég kialakított egy úgynevezett kreditmodellt is (non-linear lending), ami vásárlás esetén egy évre 325 vagy 200 egynapos, egy felhasználói elérést biztosít. Ezt a lehetőséget a keret erejéig akár egyidőben is fel lehet használni, majd a vásárlás évfordulóján az eredeti felhasználási számra (325, illetve 200) áll viszsza a rendszer. A non-linear lending forma tudomásunk szerint csak az Ebook Centralon elérhető modell.

3. Felhasználói igényen alapuló vásárlás (Demand Driven Acquistion) esetén: a könyvtár nem bizonyos címeket vásárol, hanem egy profilt alakít ki például a kulcsszavak, a kiadási év, a kiadók vagy az ár stb. alapján. A ProQuest a beállításoknak megfelelő e-könyveket a bibliográfiai adatok szintjén láthatóvá teszi, az olvasó öt percnél hosszabb aktív használattal (például böngészéssel, nyomtatással, másolással) kezdeményezheti a vásárlást. A könyvtári kontrollt az úgynevezett mediált felhasználó-vezérelt beszerzés biztosítja. Ez azt jelenti, hogy az azonnali vásárlás helyett az adminisztrátor könyvtáros kap egy automatikus értesítést az olvasó használati szándékáról, és a rendszer egyúttal engedélyt kér a dokumentum megvételére. A vásárlás kizárólag abban az esetben történik meg, ha azt a könyvtáros jóváhagyja.

4. Vásárlás előtt lehetőség nyílik egy rövidtávú kölcsönzésre (Short Term Lending STL). Ekkor a dokumentum árának 30-35\%-áért elsőként időleges elérése lesz 
a könyvtárnak az e-könyvhöz. A végleges megvételkor azonban ebben az esetben is a teljes vételárat kell fizetni.

5. Bizonyitékon alapuló vásárlás (Evidence based Acquisition) esetén: a könyvtár egy bizonyos összeget előre a szolgáltató rendelkezésére bocsát, és ezért egy megadott időszakon belül meghatározott csomagokat korlátozás nélkül ér el. Az időszak végén a használati statisztika segíti a könyvtárosokat abban, hogy az olvasói igények figyelembevételével dönthessenek a szükséges beszerzésekről.

6. Kölcsönzésböl vásárlás (Access to Own) nevü modellnél a vásárlást megelőzően kötelező az e-könyv rövid távú kölcsönzése, de a kölcsönzési összegek beszámítódnak a végső árba. Az egy éven belül kiadott könyveknél két kölcsönzésre van szükség, és kölcsönzésenként a vételár 55\%-át kell megtéríteni. A második alkalom után az e-könyv automatikusan a könyvtáré lesz. A régebben kiadott dokumentumok esetében három kölcsönzési alkalom kell, egyenként 35\%-os áron. Ennek a konstrukciónak az az előnye, hogy a vásárlás és a fizetés ideje is megnyúlik, ami egyes esetekben költségvetési szempontból előnyös lehet. Az Access to Own-modell csak a ProQuestnél érhetö el.
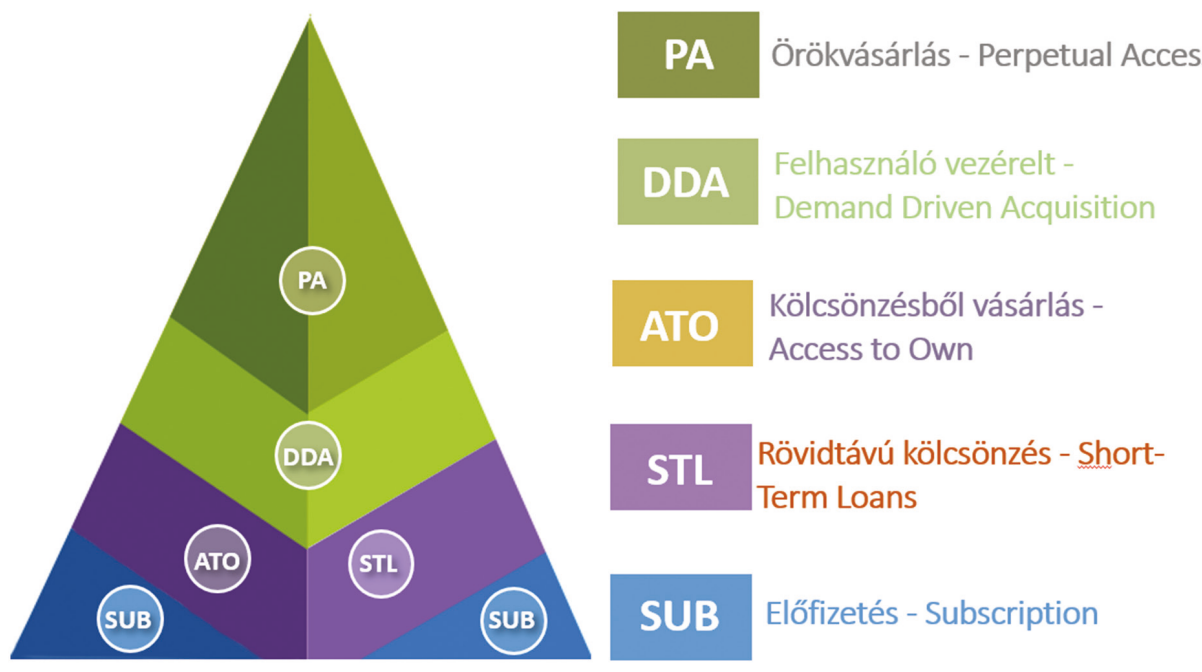

5. ábra. Az aggregálás értéke

Az e-könyvek beszerzésében elöny lehet, hogy az egyes tudományterületeken történő vásárlásokat külön lehet kezelni, külön költségvetési kódok alá gyüjteni, és azokra egyesével lehet költségküszöböket beállítani. Ennek köszönhetően egy-egy intézet, egyetemi szervezeti egység önállóan is kezelheti a saját keretét. Kényelmi funkcióként be lehet állítani értesítést a kifogyóban lévő keretekről, láthatatlanná lehet tenni az adott területnek megfelelő e-könyveket, továbbá az egyes költségkódok között át lehet csoportosítani pénzösszegeket. 
A ProQuestnél müködő, fentebb ismertetett előfizetési, beszerzési modellek elsősorban abban kívánnak segítséget nyújtani a magyarországi intézmények számára, hogy a számukra legelönyösebb konstrukciót kiválasztva minél szélesebb körben éljenek az elektronikus könyvbeszerzéssel, részesülhessenek pozitív tulajdonságaikból. Célunk hozzájárulni az e-könyvek itthoni használatának dinamikusabb növekedéséhez.

\section{Rezümé}

A ProQuest platformján, a ProQuest Ebook Centralon 1.3 millió e-könyv érhető el a felhasználók számára, ugyanitt a könyvtárosok rendelkezésére a LibCentral adminisztrátori felület áll. Ez segíti a könyvek használatának és beállításainak nyilvántartását, az olvasói adatok és szokások követését, továbbá használható a következő könyvtárosi munkafolyamatokban: beszerzés, MARC-rekordok kezelése, használati és költségstatisztikák lekérdezése.

Az elektronikus könyvek beszerzésére többféle modell áll rendelkezésre: cím szerinti vásárlás, előfizetési csomagok megrendelése vagy a felhasználó által ténylegesen használt címek beszerzése. Minden esetben az intézmény könyvvásárlási céljaival, stratégiájával egyszerre érdemes az e-könyvek beszerzéséről is dönteni. A ProQuest bővülö választékkal nyújt intézményre szabott szolgáltatásokat.

\section{Acquisition models for e-books on the ProQuest Ebook Central platform}

Over 1.3 million books are available for users on the platform of ProQuest called ProQuest Ebook Central, which offers LibCentral, a management interface for librarians as well. It makes the registration of the use of books and their settings, and the tracing of readers' data and use patterns possible, besides it can also be used in the following library processes: acquisition, handling of MARC records, compilation and downloading of statistics for use and costs.

There are several models available for the acquisition of e-books: purchase by title, packages for subscription, or the acquisition of titles actually used by readers. In every case it is worth making decisions regarding the acquisition of e-books when the overall acquisition goals and strategy of the institution is elaborated. Relying on its constantly increasing offer, ProQuest provides tailored services for every institution.

Czeglédi Éva kapcsolattartó ProQuest 